2. To: (Receiving Organization)

DISTRIBUTION

5. Proj./Prog./Dept./Div.:

8. Originator Remarks:

KEY WORDS : H2K, BMS, HANDI 2000, PEOPLESOFT GENERAL LEDGER, PROJECT

11. Receiver Remarks:

11A. Design Baseline Document?

Y. Yes

No
HANDI 2000 COSTING, BUSINESS SYSTEM IMPLEMENTATION, FINANCE, AS-IS/TO-BE

4. Related EDT No.:

$\mathrm{N} / \mathrm{A}$

7. Purchase Order No:

N/A

9. Equip./Component No:

$\mathrm{N} / \mathrm{A}$

10. System/Bidg./Facility;

$\mathrm{N} / \mathrm{A}$

12. Major Assm. Dwg. No.:

N/A

13. Permit/Permit Application No.:

$\mathrm{N} / \mathrm{A}$

14. Required Response Date:

N/A

\begin{tabular}{|l|c|}
\hline $\begin{array}{c}\text { (A) } \\
\text { Item } \\
\text { No. }\end{array}$ & (B) Dociment/Drawing No. \\
\hline 1 & HNF-2640 \\
\hline & HNF-2641 \\
\hline 2 & HNF-2642 \\
\hline 3 & $\ddots$ \\
\hline & (SEE SHEET 2) \\
\hline
\end{tabular}

\section{DATA TRANSMITTED}

16.

\begin{tabular}{|l|c|l|}
\hline $\begin{array}{c}\text { (C) Sheet } \\
\text { No. }\end{array}$ & $\begin{array}{c}\text { (O) Rev. } \\
\text { No. }\end{array}$ & (E) Title or Description of Data Transmitted \\
\hline N/A & 0 & ACCRUALS FOR HANDI 2000 \\
\hline & & BUSINESS MANAGEMENT SYSTEM \\
\hline N/A & 0 & ALLOCAT IONS FOR HANDI 2000 \\
\hline N/A & 0 & BUDGET FOR HANDI 2000 \\
\hline & & BUSINESS MANAGEMENT SYSTEM \\
\hline
\end{tabular}

\begin{tabular}{|c|c|c|c|}
\hline (F) & (G) & $(H)$ & $(\mathrm{I})$ \\
\hline $\begin{array}{c}\text { Approval } \\
\text { Desig- } \\
\text { nator }\end{array}$ & $\begin{array}{c}\text { Reason } \\
\text { mittal } \\
\text { mita- }\end{array}$ & $\begin{array}{c}\text { Origi- } \\
\text { nator } \\
\text { Dispo- } \\
\text { stion }\end{array}$ & $\begin{array}{c}\text { Receiv- } \\
\text { er } \\
\text { Dispo- } \\
\text { sition }\end{array}$ \\
\hline N/A & 2 & & \\
\hline N/A & 2 & & \\
\hline N/A & 2 & & \\
\hline
\end{tabular}

KEY

\begin{tabular}{|c|c|c|c|c|}
\hline Approval Designator $(F)$ & \multicolumn{2}{|c|}{ Reason for Transmittal (G) } & \multicolumn{2}{|c|}{ Disposition (H) \& (I) } \\
\hline $\begin{array}{l}\text { E, S, Q, D OR N/A } \\
\text { (See WHC-CM-3-5, } \\
\text { Sec. 12.7) }\end{array}$ & $\begin{array}{l}\text { 1. Approval } \\
\text { 2. Release } \\
\text { 3. Information }\end{array}$ & $\begin{array}{l}\text { 4. Review } \\
\text { 5. Post-Review } \\
\text { 6. Dist. (Receipt Acknow. Required) }\end{array}$ & $\begin{array}{l}\text { 1. Approved } \\
\text { 2. Approved w/comment } \\
\text { 3. Disapproved w/comment }\end{array}$ & $\begin{array}{l}\text { 4. Revjewed no/comment } \\
\text { 5. Reviewed w/comment } \\
6 \text {. Receipt acknowledged }\end{array}$ \\
\hline
\end{tabular}
17.

(See Approval Designator for required signatures)

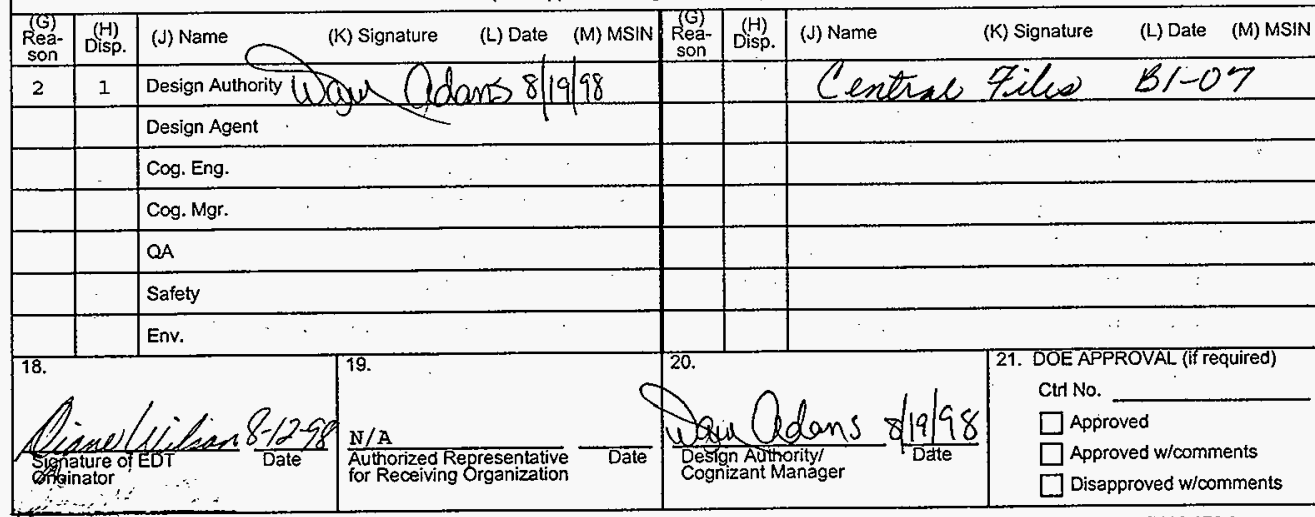




\begin{tabular}{|c|c|c|c|c|c|c|c|c|}
\hline \multirow{2}{*}{\multicolumn{2}{|c|}{\begin{tabular}{|l}
$\cdots$ \\
5. Proj./Prog./Dept.Div.: \\
HANDI 2000
\end{tabular}}} & \multicolumn{7}{|c|}{$\begin{array}{l}\text { ENGINEERING DATA TRANSMITTAL } \\
\text { (CONTINUATION PAGE) }\end{array}$} \\
\hline & & \multicolumn{3}{|c|}{$\begin{array}{l}\text { 6. Cog. Eng. } \\
\text { DAWN E. ADAMS }\end{array}$} & \multicolumn{2}{|l|}{$\begin{array}{l}\text { 1. EDT } \\
625358\end{array}$} & \multicolumn{2}{|c|}{ Page 2 of 4} \\
\hline \multicolumn{2}{|l|}{15.} & \multicolumn{3}{|c|}{ DATA TRANSMITTED } & (F) & (G) & (H) & (I) \\
\hline $\begin{array}{l}\text { (A) } \\
\text { Item } \\
\text { No. }\end{array}$ & (B) Document/Drawing No. & $\begin{array}{l}\text { (C) } \\
\text { sheet } \\
\text { No. }\end{array}$ & $\begin{array}{l}\text { (D) } \\
\text { Rev. } \\
\text { No. }\end{array}$ & $\begin{array}{l}\text { (E).Title or Description of Data } \\
\text { Transmitted }\end{array}$ & $\begin{array}{l}\text { Approval } \\
\text { Desig- } \\
\text { nator }\end{array}$ & \begin{tabular}{|c|} 
Reason \\
for \\
Trans- \\
mittal \\
\end{tabular} & $\begin{array}{l}\text { Origi- } \\
\text { nator } \\
\text { Dispo- } \\
\text { stion }\end{array}$ & $\begin{array}{c}\text { Receiv- } \\
\text { er } \\
\text { Dispo- } \\
\text { sition }\end{array}$ \\
\hline \multirow[t]{3}{*}{4} & $\mathrm{HNF}-2746$ & $\mathrm{~N} / \mathrm{A}$ & 0 & FIT GAP ANALYSIS FOR & $\mathrm{N} / \mathrm{A}$ & 2 & & \\
\hline & & & & HANDI 2000 BUSINESS & & & & \\
\hline & & & & MANAGEMENT SYSTEM & & & & \\
\hline \multirow[t]{3}{*}{5} & HNF -2643 & $\mathrm{~N} / \mathrm{A}$ & 0 & CLOSING PROCEDURE FOR & $\mathrm{N} / \mathrm{A}$ & 2 & & \\
\hline & & & & HANDI 2000 BUSINESS & & & & \\
\hline & & & & MANAGEMENT SYSTEM & & & & \\
\hline \multirow[t]{3}{*}{6} & $\mathrm{HNF}-2644$ & $\mathrm{~N} / \mathrm{A}$ & 0 & FIXED ASSETS ACCOUNTING & $\mathrm{N} / \mathrm{A}$ & 2 & & \\
\hline & & & & FOR HANDI 2000 BUSINESS & & & & \\
\hline & & & & MANAGEMENT SYSTEM & & & & \\
\hline \multirow[t]{3}{*}{$7:$} & HNE -2645 & $\mathrm{~N} / \mathrm{A}$ & 0 & FUNDS CONTROI FOR HANDI & $\mathrm{N} / \mathrm{A}$ & 2 & & \\
\hline & & & & 2000 BUSINESS MANAGEMENT & & & & \\
\hline & & & & SYSTEM & & & & \\
\hline \multirow[t]{4}{*}{8} & HNF -2646 & $\mathrm{~N} / \mathrm{A}$ & 0 & GL CHART OF ACCOUNTS & $\mathrm{N} / \mathrm{A}$ & 2 & & \\
\hline & & . & & MAINTENANCE FOR HANDI & & & & \\
\hline & & & & 2000 BUSINESS MANAGEMENT & & & & \\
\hline & & & & SYSTEM & & & & \\
\hline \multirow[t]{3}{*}{9} & HNF -2647 & $\mathrm{~N} / \mathrm{A}$ & 0 & HANFORD BUSINESS. & $\mathrm{N} / \mathrm{A}$ & 2 & & \\
\hline & & & & STRUCTURE FOR BUSINESS & & & & \\
\hline & & & & MANAGEMENT SXSTEM & & & & \\
\hline \multirow[t]{3}{*}{10} & HNF -2648 & $\mathrm{~N} / \mathrm{A}$ & 0 & INVENTORY PROCESSES & $N / A$ & 2 & & \\
\hline & & & & FOR HANDI 2000 BUSINESS & & & & \\
\hline & & & & MANAGEMENT SYSTEM & & & & \\
\hline \multirow[t]{3}{*}{11} & HNF -2649 & $\mathrm{~N} / \mathrm{A}$ & 0 & INVOICE/DISCAS FOR HANDI & $\mathrm{N} / \mathrm{A}$ & 2 & & \\
\hline & & & & 2000 BUSINESS MANAGEMENT & & & & \\
\hline & & & & SYSTEM & & & & \\
\hline \multirow[t]{3}{*}{12} & HNF - 2650 & $\mathrm{~N} / \mathrm{A}$ & 0 & LABOR COSTING FOR HANDI & $\mathrm{N} / \mathrm{A}$ & 2 & & \\
\hline & & & & 2000 BUSINESS MANAGEMENT & & & & \\
\hline & & & & SYSTEM & & & & \\
\hline \multirow[t]{5}{*}{13} & HNF -2651 & $\mathrm{~N} / \mathrm{A}$. & 0 & PASSPORT-PEOPLESOFT & $\mathrm{N} / \mathrm{A}$ & 2 & & \\
\hline & & & & INTEGRATION FOR HANDI & & & & \\
\hline & & & & 2000 BUSINESS MANAGEMENT & & & & \\
\hline & & & & SYSTEM & & & & \\
\hline & (CONTINUED ON PG 3) & & & & & & & \\
\hline
\end{tabular}




\section{ENGINEERING DATA TRANSMITTAL}

(CONTINUATION PAGE)

5. Proj/Prog./Dept.Div.:

HANDI 2000
6. Cog. Eng.

DAWN E. ADAMS
1. EDT

625358

DATA TRANSMITTED

15.

(A)
item

No.

(B) DocumentDrawing No.

(C)

Sheel
No.

(D)

No.

\begin{tabular}{|l|l|}
\hline 14 & HNF - 2652 \\
\hline
\end{tabular}

\begin{tabular}{|l|l|}
\hline & \\
\hline & \\
\hline 15 & HNF-2653 \\
\hline
\end{tabular}

$\mathrm{N} / \mathrm{A}$

0 UNIT BILLED SERVICES FOR

HANDI 2000 BUSINESS

MANAGEMENT SYSTEM

OTS CASH DISBURSEMENT

PROCESS FOR BUSINESS

MANAGEMENT SYSTEM

\begin{tabular}{l|l}
\hline 16 & HNF -265 \\
\hline
\end{tabular}

\begin{tabular}{l|l}
17 & HNF -2655 \\
\hline
\end{tabular}

N/A

O TRAVEL EXPENSE

REIMBURSEMENT FOR HANDI

2000 BUSINESS MANAGEMENT

SYSTEM

\begin{tabular}{ll|l|l} 
CASH RECEIPTS PROCESS FOR & N/A & 2
\end{tabular}

HANDI 2000 BUSINESS

MANAGEMENT SYSTEM

$18 \quad \mathrm{HNF}-2656$

$\mathrm{N} / \mathrm{A}$

0

INSURANCE PAYMENT PROCESS

FOR HANDI 2000 BUSINESS

MANAGEMENT SYSTEM

19 HNF-2658

$\mathrm{N} / \mathrm{A}$

0 .

SAVINGS PLAN PAYMENT

PROCESS FOR HANDI 2000

BUSINESS MANAGEMENT

SYSTEM

\begin{tabular}{l|l}
20 & HNF -2659 \\
\hline
\end{tabular}

$\mathrm{N} / \mathrm{A}$

0

WORK PERFORMED BY ENTER-

PRISE COMPANIES (ENCO)

FOR (PHMC) FOR HANDI 2000

BUSINESS MANAGEMENT

SYSTEMS

21 HNF-2661

\begin{tabular}{l|l}
\hline $\mathrm{N} / \mathrm{A}$ & 0 \\
\hline
\end{tabular}

WORK PERFORMED BY PHMC

FOR OHC-WORK ORDER FOR

HANDI 2000 BUSINESS

MANAGEMENT SYSTEM

\begin{tabular}{|l|l|}
\hline 22 & HNF -266 \\
\hline
\end{tabular}

0

WORK PERFORMED BY OHC FOR

PHMC-WORK ORDER PROCESS

FOR HANDI 2000 BUSINESS

(CONTINUED ON PG 4)

(F)

Page 3 of 4

\begin{tabular}{|c|c|c|c|}
\hline$(\boldsymbol{F})$ & $(\mathrm{G})$ & $(\mathrm{H})$ & $(\mathrm{l})$ \\
\hline $\begin{array}{c}\text { Approval } \\
\text { Desig- } \\
\text { nator }\end{array}$ & $\begin{array}{c}\text { Reason } \\
\text { for } \\
\text { rans- } \\
\text { mittal }\end{array}$ & $\begin{array}{c}\text { Origi- } \\
\text { nator } \\
\text { Dispo- } \\
\text { stion }\end{array}$ & $\begin{array}{c}\text { Receiv- } \\
\text { er } \\
\text { Dispo } \\
\text { sition }\end{array}$ \\
\hline & & &
\end{tabular}




\begin{tabular}{|c|c|c|c|c|c|c|c|c|}
\hline & $\cdots$ & ENGIN & $\begin{array}{l}\text { RIN } \\
\text { (CON }\end{array}$ & $\begin{array}{l}\text { DATA TRANSMITTAL } \\
\text { IINUATION PAGE) }\end{array}$ & & & & \\
\hline $\begin{array}{l}\text { 5. Proj } \\
\text { HAI }\end{array}$ & $\begin{array}{l}\text { Prog.dDept.Div.: } \\
\text { DI } 2000\end{array}$ & $\begin{array}{r}\text { 6. CO } \\
\mathrm{DA}\end{array}$ & E. & DAMS & $\begin{array}{l}1 . \text { EDT } \\
625358\end{array}$ & & ge $4 \quad 0$ & \\
\hline 15. & & DATA TF & ISMITT & & (F) & (G) & (H) & (I) \\
\hline $\begin{array}{l}\text { (A) } \\
\text { Item } \\
\text { No. }\end{array}$ & (B) Document/Drawing No. & $\begin{array}{l}\text { (C) } \\
\text { Sheet } \\
\text { No. }\end{array}$ & $\begin{array}{l}\text { (D) } \\
\text { Rev. } \\
\text { No. }\end{array}$ & $\begin{array}{l}\text { (E) Title or Description of Data } \\
\text { Transmitted }\end{array}$ & $\begin{array}{c}\text { Approval } \\
\text { Desig- } \\
\text { nator }\end{array}$ & $\begin{array}{c}\text { Reason } \\
\text { for } \\
\text { Trans- } \\
\text { mittal } \\
\end{array}$ & $\begin{array}{c}\text { Origi- } \\
\text { nator } \\
\text { Dispo- } \\
\text { stion } \\
\end{array}$ & $\begin{array}{c}\text { Receiv- } \\
\text { er } \\
\text { Dispo- } \\
\text { sition } \\
\end{array}$ \\
\hline 23 & HNF-2663 & $\mathrm{N} / \mathrm{A}$ & 0 & WALK-IN WORK FOR OTHER & $\mathrm{N} / \mathrm{A}$ & 2 & & \\
\hline & & & & HANFORD CONTRACTORS FOR & & & & \\
\hline & . & & & HANDI 2000 BUSINESS & & & & \\
\hline & & & & MANAGEMENT SYSTEM & & & & \\
\hline 24 & HNF - 2664 & $\mathrm{~N} / \mathrm{A}$ & 0 & DOE HANFORD REQUEST FOR & & & & \\
\hline & & & & SERVICES FOR HANDI 2000 & & & & \\
\hline & & & & BUS INESS MANAGEMENT & & & & \\
\hline & . & & & SYSTEM & & & & \\
\hline & & & & & & & & \\
\hline & & 5 & & & & & & \\
\hline & & & & & & & & \\
\hline & & & & . & & & & \\
\hline & & & & & & & & \\
\hline & & & & & & & & \\
\hline & & & & & & & & \\
\hline & & & & & & & & \\
\hline & & & & & & & & \\
\hline & & & & & & & & \\
\hline & & & & & & & & \\
\hline & & & & & & & & \\
\hline & & & & & & & & \\
\hline & & & & & & & & \\
\hline & & & & & & & & \\
\hline & & & & & & & & \\
\hline & & & & . & & & & \\
\hline & & & & & & & & \\
\hline & & & & & & & & \\
\hline & & & & & & & & \\
\hline & & & & & & & & \\
\hline & & & & & & . & & \\
\hline & & & & & & & & \\
\hline & & & & & & & & \\
\hline & & & & & & & & \\
\hline
\end{tabular}




\title{
LABOR COSTING FOR HANDI 2000 BUSINESS MANAGEMENT SYSTEM
}

Diane Wilson, Fluor Daniel Hanford Co.

MSN $31-22,2355$ stevens

Richland, WA 99352

U.S. Department of Energy Contract DE-AC06-96RL13200

\author{
EDT/ECN: 625358 \\ UC: 900 \\ Org Code: FK260000 \\ B\&R Code: 7070100 \\ Charge Code: \\ Total Pages: \\ $\operatorname{los}^{8}{ }^{\text {YBPME }}$
}

Key Words: As-Is/To-Be Procedures, Charts

Abstract: Costing labor in the Financial Data System has traditionally been done using standard rates based on type of employee by organiation. This methodology will change with the implementation of the peoplesoft financial system. Labor in the new environment will be cost against actual doddars and marked up with an employee adder. (to cover absences and frings benefits)

TRADEMARK DISCLAIMER. Reference herein to any specific commercial product, process, or service by trade name, trademark, manufacturer, or otherwise, does not necessarily constitute or imply its endorsement, recommendation, or favoring by the United States Government or any agency thereof or its contractors or subcontractors.

Printed in the United States of America. To obtain copies of this document, contact: Document Control Services, P.O. Box 950, Mailstop H6-08, Richland WA 99352, Phone (509) 372-2420; Fax (509) 376-4989.

PeopleSoft is a trademark of Indus corp.
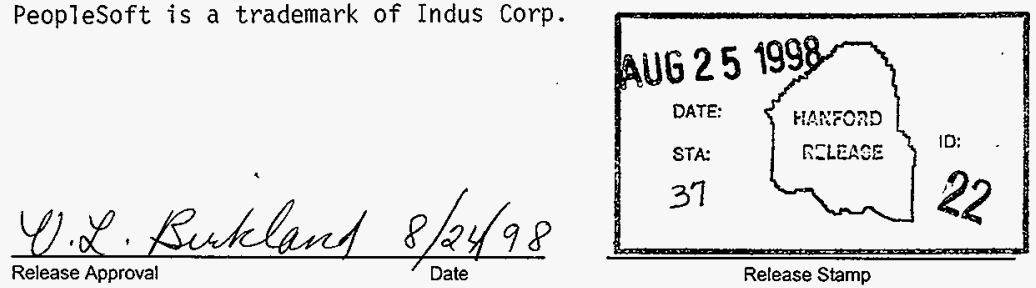

Release Stamp 


\section{Memorandum}

To:
D.E. Adams
G1-21
K.B. Adamsons H2-19
M.J. Byrd H2-08,
R.C. Corless H2-19,
A.A. Carter H2-19,
J.A. Caldwell G1-22,
C.R. Hopkins G1-57,
R.J. McFadzean H2-19

From: P. C. Felts

Date: April 17, 1998

Re: PeopleSoft General Ledger / Project Costing -- Business System Implementation Sessions Final Documentation

\section{HANDI 2000 - Finance}

Attached for your information is the complete set of documentation of the work flow analysis from the Business System Implementation (BSI) Sessions.

One of the goals of finalizing documentation from the BSI Sessions is to use the documents as a communication tool.

Other goals of the BSI sessions were to validate the As-Is process, and describe the vision of the To-Be process that fit the baseline software processes. In the future, this documentation will be accessible electronically via a read-only shared area.

I thank you and your staff for your support during this information gathering and envisioning stage of the new system implementation project

If you have any questions, I can be reached on 376-0367 or via email.

Artachment 
Date: $\quad 4 / 17 / 98$

Documentation: Finance Business System Implementation (BSI) Sessions

Processes Included:

- Accrual

- Allocations

- Budget

- Fit-Gap Analysis

- Closing Procedure

- Fixed Assets Accounting

- Funds Control

- General Ledger Account Maintenance

- Hanford Business Structure

- Inventory Processes

- Invoice/DISCAS

- Labor Costing

- Passport-PeopleSoft Integration

- Unit Billed Service

- Travel \& Treasury:

- OTS Cash Disbursement Process

- Travel Expense Reimbursement

- Cash Receipt Process.

- Savings, Pensions, \& Insurance:

_ Insurance Payment Process

- Pension Payment Process

- Savings Plan Payment Process

Other Hanford Contractors:

- Worked Performed by Enco's for PHMC

- Worked Performed by Enco's for OHC

- Worked Performed by PHMC for OHC - Work Order

- Worked Performed by OHC for PHMC - Work Order Process

- Worked Performed by PHMC for OHC - Walk In

- Worked Performed by PHMC for DOE-Richland using the Request for Service Process

FDH Project Lead: $\quad$ Name

Signature

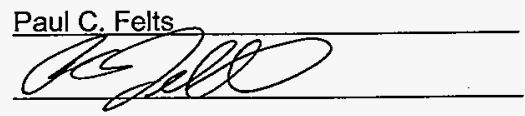




\section{Labor Costing}

\section{Overview}

Costing labor in the Financial Data System (FDS) has traditionally been done using standard rates based on type of employee (exempt, non-exempt or bargaining) by organization. This methodology will change with the implementation of the PeopleSoft financial system. Labor in the new environment will be costed against actual dollars and marked up with an employee adder (to cover absences and fringe benefits).

\section{Assumptions}

- Actuals will be costed and priced.

$\square$ Payroll will price labor and provide the costed hours for application of employee adder.

TIS will remain the point of time entry.

TIS will edit time and charge data prior to upload into the Financial/HR system

TIS correction entries will flow through as offsetting entries to previous time charged as in the current system.

$\square$ The Pricing Table will contain priced labor history for audit purposes

\section{Policies}

Employees will have to charge their time to Project ID and Code of Account

Employees will continue to utilize TIS to classify time and work

\section{As-is Procedures}

1. Employee enters time and charge code data into TIS.

2. TIS performs a validation edit of the information, allowing the user to override any errors the system finds.

3. FDS (utilizing the hourly data provided by TIS) applies standardized rates (by organization) table to price the labor.

4. Payroll utilizing TIS data costs using actual labor rates,

5. FDS updates the General Ledger and Project Expense.

6. General Ledger variances between standard labor costs and actual payroll costs are adjusted periodically (and always at year-end). 


\section{To-Be Procedures}

1. Employee enters time and charge code data into TIS

2. TIS will edit entered data. If edits fail, employee will have to correct time and charge code information. If edits are successful, employee will submit TIS file to TIS system.

3. HR/Payroll will take final TIS record and update HR and Payroll records.

4. HR/Payroll will generate a payroll from the updated time and labor information. While also updating the Labor Cost record for the Financial system to utilize.

5. Labor Cost record will be calculated by dividing (allocating) total gross payroll by actual hours worked by Project ID. Overtime will be calculated separate from regular time.

6. The labor costing interface will apply an employee adder (for absences and fringe benefits) on to costed labor and create the labor entry to PeopleSoft Project Costing. The labor costing interface will also provide Handi with a report of Employee/Hrs/Charge Code. Project Costing will create a journal entry into General Ledger (using the Projects journal generator).

\section{Impacts}

- TIS will have to be modified to accommodate the new Hanford Business Structure. Furthermore TIS will no longer allow invalid data to uploaded to the Financials and HR systems. This will require TIS to fatal error on any bad or out dated charge code information.

B Bargaining unit employees are paid weekly while non-bargaining (non-exempt and exempt employees) are paid bi-weekly in the current payroll payment processing schedule. As a result, payroll actuals include only bargaining unit employee pay one week, and all employee pay the next week. Depending on the timing of the fiscal month calendar (4/4/5 week calendar), labor costs will either be current (an all employee pay process) or labor costs for non-bargaining employees will be behind one week (a bargaining employee only pay process). This lagging week will constitute exempt and non-exempt labor hours that have been worked, but not yet paid. This lagging weekly labor will occur in 5 of the 12 fiscal month-ends in a year (excluding fiscal year-end).

\section{Issues \& Action Items}

\section{Issues/Action items}

The modification/reprogramming of TIS is predicated on Hanford Business Structure (HBS). Programming requirements need to be developed for TIS to support the new Hanford Business Structure.

$\square$ Will the one week time lag for all salaried employees for the five week financial periods be an issue for project management or does some type of accrual for the week lag need to be developed? Actionee: Dick Pouley to obtain decision from FDH management.

- The data archieve strategy for the pricing table still has to be determined. This decision will be predicated on the needs of DOE, IG, DCAA, and other auditors. Actionee: Dick Pouley 
$\square$ The level of labor detail maintained in PeopleSoft needs to be determined. Data includes level of dept. id (how low), labor type (regular or OT), employee type (exempt, non-exempt, bargaining; COCS category). Actionee: Dick Pouley to obtain decision from FDH management.

\section{Labor Costing Process Model - As Is}


TIS Data Entry

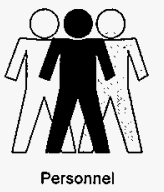

TIS Data Edit

Payroll Update

Pricing Update

$$
\begin{aligned}
& \text { Employee Id } \\
& \text { Project Id } \\
& \text { Code of Accounts } \\
& \text { Attendance Code } \\
& \text { Hours Worked }
\end{aligned}
$$

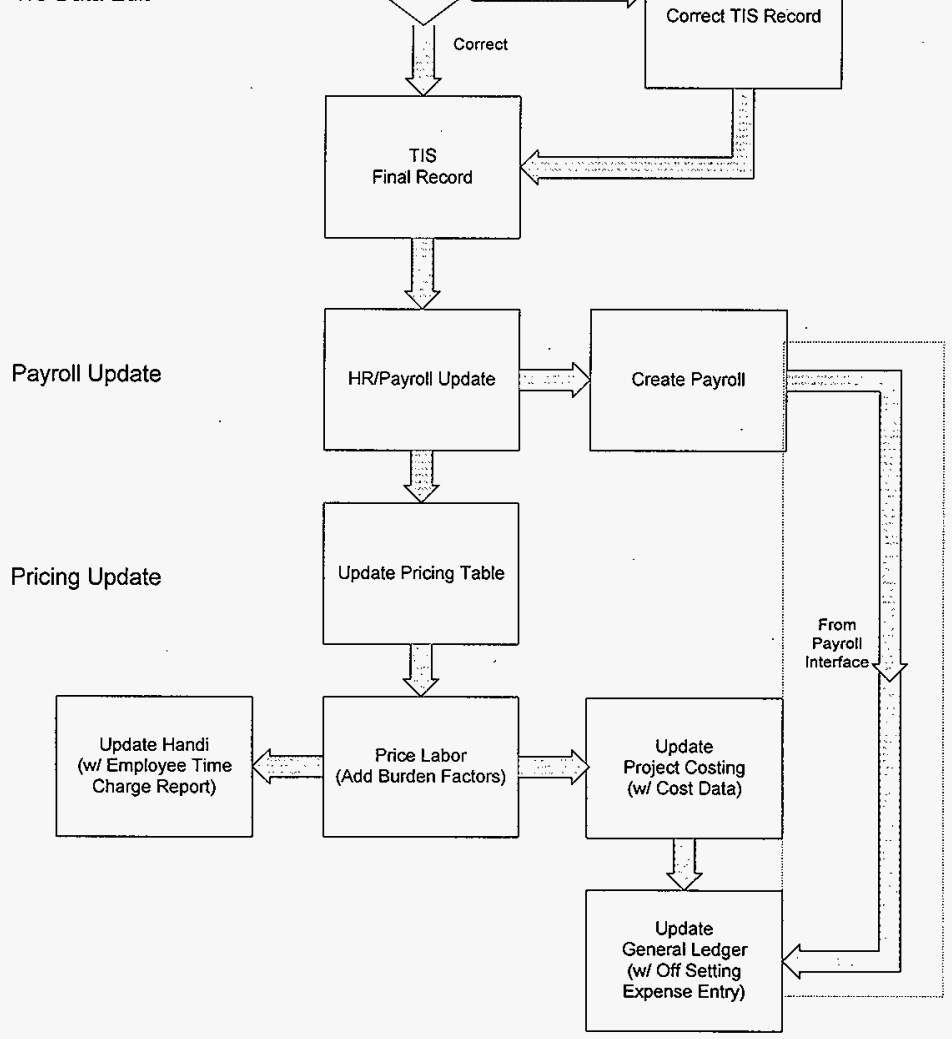


TIS Data Entry

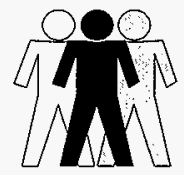

Personnel

TIS Data Edit

GL/Project

Costing

Update

Hanford ID

Charge Code (TPCN)

Attendence Code

Hours Worked

Payroll/Pricing

Update

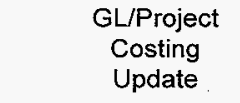

FDS

General

Ledger

Correct

or

Override

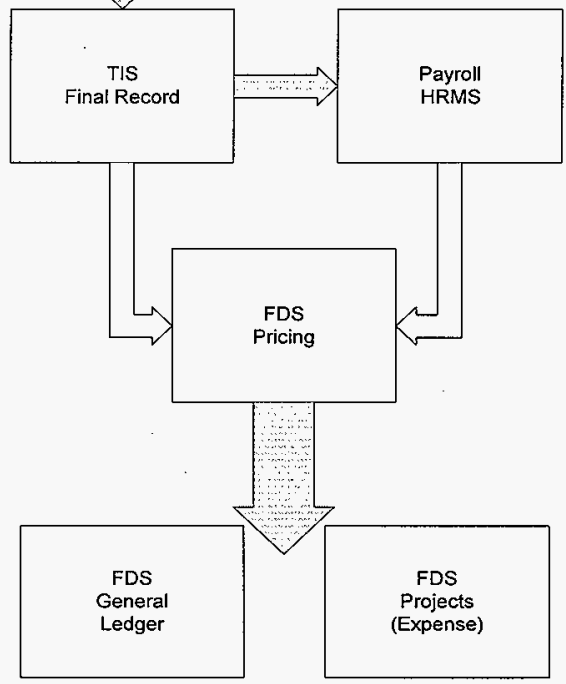

\section{Labor Costing Process Model - To Be}

